\title{
Pengaruh Bahan Tambah Gula Pasir Terhadap Waktu Pengikatan dan Kuat Tekan
}

\section{RETNO TRIMURTININGRUM,BANTOT SUTRIONO, BILLY ARROWRICHTA, HIASINTUS BERTUS WATU, MISRAWI}

\author{
Fakultas Teknik, Universitas 17 Agustus 1945 Surabaya \\ Email: retnotrimurti@untag-sby.ac.id
}

\begin{abstract}
ABSTRAK
Dalam pelaksanaan pembangunan konstruksi beton, seringkali ditemui beberapa kendala, seperti lokasi batching plan yang berbeda dengan lokasi proyek serta tingginya temperatur saat pengecoran, sehingga dapat mempercepat waktu pengikatan beton. Untuk mencegah waktu pengikatan lebih awal, diperlukan bahan tambah kimia yang dapat memperlambat waktu pengikatan yaitu retarder. Akan tetapi, bahan tambah kimia mempunyai harga yang relatif tinggi. Oleh karena itu, pada penelitian ini digunakan gula sebagai bahan tambah alternatif, karena gula merupakan salah satu penyusun dalam komposisi retarder serta mempunyai harga yang cukup ekonomis. Persentase gula pasir yang digunakan bervariasi, yaitu 0\% (sebagai benda uji kontrol); 0,03\%; 0,05\% dan 0,1\%. Hasil pengujian menunjukkan waktu pengikatan terlama diperoleh campuran dengan persentase gula sebanyak 0,1\% dengan waktu ikat awal 157 menit dan waktu ikat akhir 258 menit, sedangkan hasil pengujian kuat tekan maksimum sebesar $225,38 \mathrm{~kg} / \mathrm{cm}^{2}$ diperoleh campuran dengan persentase gula sebanyak 0,05\%.
\end{abstract}

Kata kunci; waktu pengikatan, gula, kuat tekan, retarder

\begin{abstract}
In concrete construction process, several obstacles are often to be encountered such as the location of the batching plan that is different from the project location, as well as the high temperature while casting causes the acceleration of concrete setting time. To prevent earlier setting time, chemical admixture which can slow down the setting time is needed, namely retarders. However, chemical admixtures have relatively high prices. Therefore, in this study, sugar was used as an alternative ingredient, because sugar is one of the retarder's composition and has relatively economical price. The percentages of sugar were varied, which are $0 \%$ (as a control specimen); $0.03 \% ; 0.05 \%$ and $0.1 \%$. The test results showed that the longest setting time is obtained by mixture with $0.1 \%$ of sugar, with the initial setting time 157 minutes and the final setting time 258 minutes, while the maximum compressive strength test results are $225,38 \mathrm{~kg} / \mathrm{cm}^{2}$ obtained by a mixture with 0,05\% of sugar.
\end{abstract}

Keywords: setting time, sugar, compressive strength, retarder 


\section{PENDAHULUAN}

Penggunaan beton dan mortar sebagai material konstruksi sangat luas. Berbagai macam bangunan seperti: rumah, gedung, jembatan, waduk, saluran serta jalan layang; menggunakan campuran beton maupun mortar. Dalam pelaksanaan pembangunannya, seringkali kontraktor dihadapkan oleh beberapa permasalahan, seperti lokasi batching plan yang lokasinya cukup jauh dengan lokasi pembangunan proyek sehingga dibutuhkan beberapa waktu untuk kemudian sampai ke lokasi proyek dan siap digunakan serta tingginya temperatur pada saat pengecoran sehingga dapat mempercepat waktu pengikatan campuran. Oleh karena itu, waktu pengikatan menjadi salah satu hal yang harus diperhatikan. Untuk mencegah terjadinya waktu pengikatan yang lebih cepat, maka diperlukan bahan tambah kimia yang berfungsi untuk menunda waktu pengikatan.

Retarder merupakan salah satu bahan tambah chemical admixture yang berfungsi untuk memperlambat waktu pengikatan pasta semen. Retarder mencegah terjadinya cold joint serta sangat bermanfaat dalam pengecoran dengan cuaca bertemperatur tinggi (Neville, 2010). Mekanisme kerja retarder adalah penyerapan molekul retarder pada permukaan semen sehingga terbentuk pelindung yang mencegah semen untuk bereaksi dengan air (Khan, B., 2004). Penggunaan bahan tambah kimia pada campuran beton biasanya mempunyai biaya yang relatif tinggi dan biasanya bahan tambah kimia juga cukup sulit untuk didapatkan khususnya pada daerah yang jauh dari perkotaan (Bunganaen, 2016). Menurut Neville, peristiwa perlambatan waktu ikat retardation dapat ditimbulkan dengan penambahan gula, karbohidrat dan turunannya, larutan garam seng, larutan borat dan lainlain (Neville, 2010).

Oleh karena itu, pada penelitian digunakan gula pasir sebagai bahan tambah alternatif karena gula merupakan salah satu penyusun dalam komposisi retarder serta mempunyai harga yang cukup ekonomis dan mudah didapatkan. Pada penelitian ini menggunakan benda uji berupa pasta semen (yaitu campuran yang terdiri dari semen dan air yang digunakan untuk uji waktu pengikatannya) serta benda uji mortar (yaitu campuran yang terbuat dari pasta semen dan agregat halus) untuk mengetahui pengaruh bahan tambah gula pasir terhadap hasil uji tekan.

\section{TINJAUAN PUSTAKA}

\subsection{Setting Time}

Waktu pengikatan (setting time) adalah waktu dimana terjadi perubahan pasta semen dari kondisi cair menjadi kondisi padat (Neville, 2010). Waktu pengikatan dimulai dihitung saat pertama kali semen bercampur dan bereaksi dengan air. Waktu pengikatan dibagi menjadi 2 tahap, yaitu: initial setting (waktu ikat awal) dan final setting (waktu ikat akhir). Waktu pengikatan awal adalah waktu yang dibutuhkan saat semen dicampur dengan air sehingga berubah kondisinya dari kondisi plastis menjadi tidak plastis; sedangkan waktu pengikatan akhir adalah waktu yang dibutuhkan saat semen dicampur dengan air sehingga berubah kondisinya dari kondisi plastis menjadi "keras" (Subakti, A., 2010). Pengujian waktu pengikatan pasta semen berdasarkan SNI 03-6826-2002dan SNI 03-6827-2002.

\subsection{Kuat Tekan}

Kuat tekan dihitung berdasarkan perbandingan gaya terbesar yang mampu dipikul benda uji sesaat sebelum pecah dibagi luasan penampang benda uji. Pengujian kuat tekan mortar dilakukan berdasarkan SNI 03-6825-2002.

Rumus perhitungan kuat tekan adalah seperti tertera pada Persamaan 1 berikut: 


$$
\sigma_{m}=\frac{P_{m a k s}}{A}
$$

halmana:

$\begin{array}{ll}\sigma_{m} & =\text { kuat tekan benda uji mortar }\left[\frac{\mathrm{kg}}{\mathrm{cm}^{2}}\right], \\ P_{\text {maks }} & =\text { gaya tekan terbesar }[\mathrm{kg}], \\ A & =\text { luasan penampang benda uji }\left[\mathrm{cm}^{2}\right] .\end{array}$

\section{METODOLOGI PENELITIAN}

\subsection{Diagram Alir Penelitian}

Tahapan penelitian dapat dilihat di diagram alir penelitian pada Gambar $\mathbf{1}$ di bawah ini:

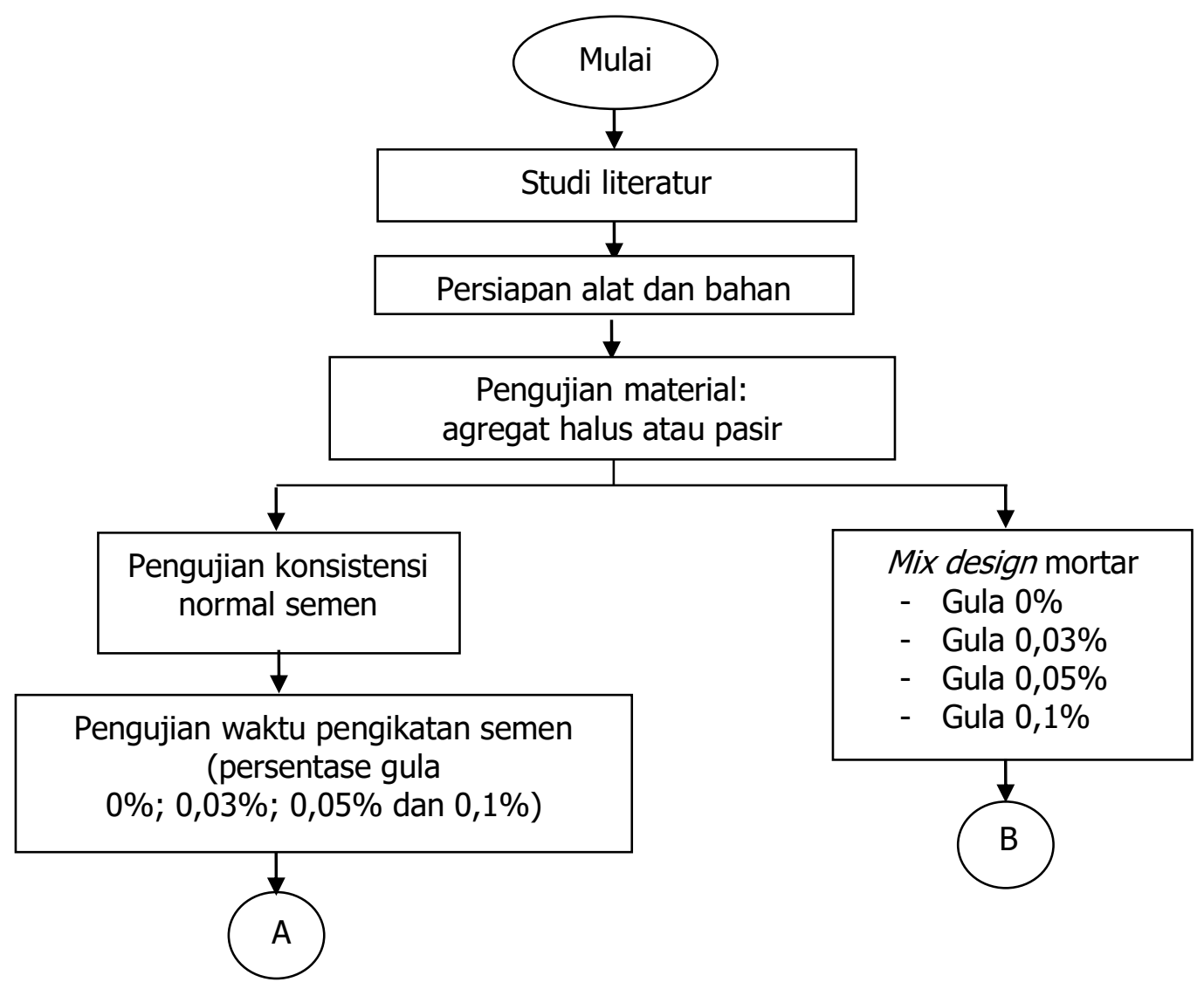

Gambar 1. Diagram alir penelitian 


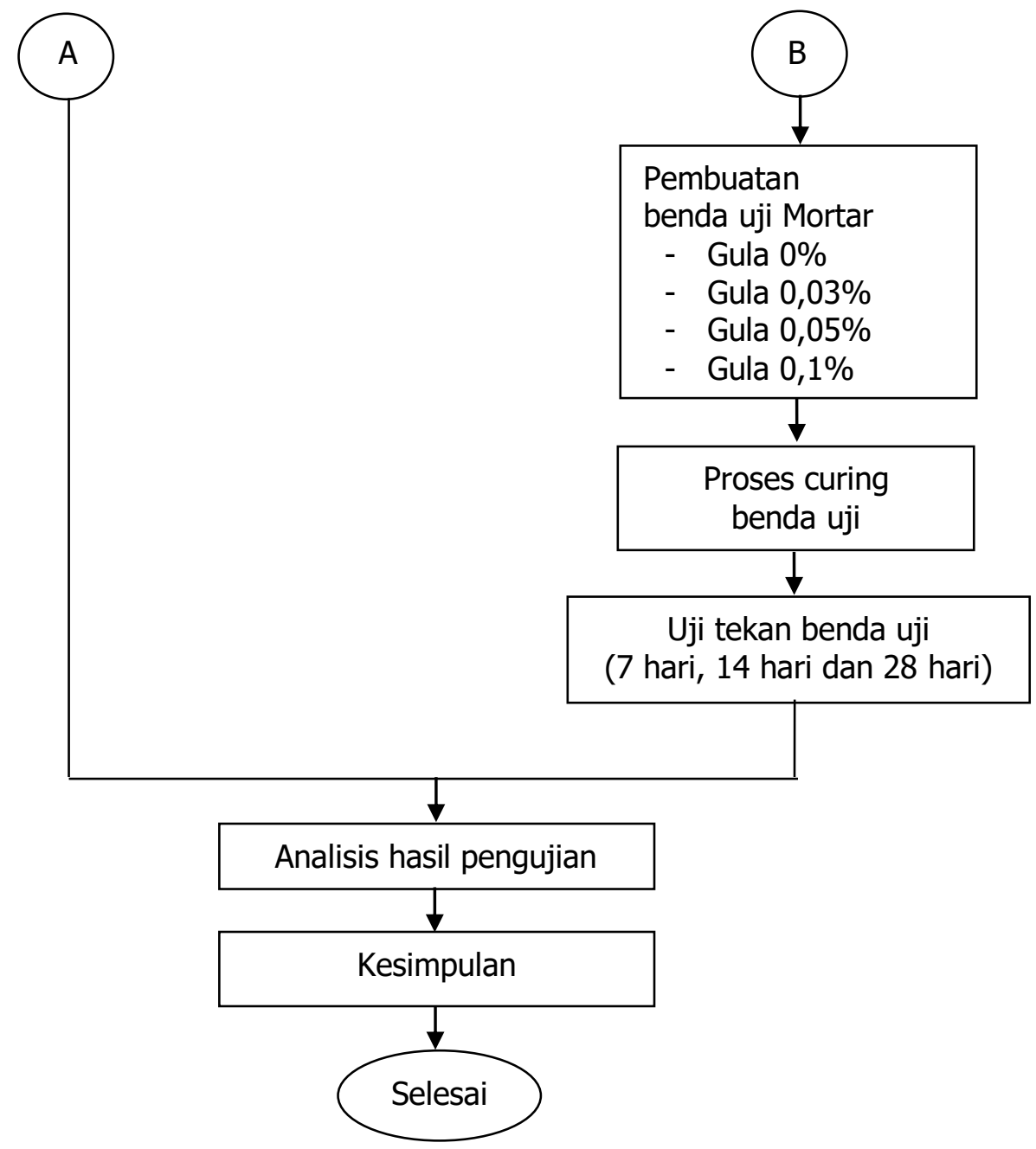

Gambar 1. Diagram alir penelitian (lanjutan)

\subsection{Material}

Material yang digunakan dalam penelitian ini adalah sbb.:

- Agregat Halus

Penelitian ini menggunakan agregat halus yang berasal dari Pasir Lumajang. Hasil pengujian material agregat halus disampaikan dalam Tabel 1 dan Gambar $\mathbf{2}$ berikut: 
Tabel 1. Hasil Pengujian Analisis Ayakan Pasir

\begin{tabular}{|c|c|c|c|c|c|}
\hline \multicolumn{2}{|c|}{ Saringan } & \multirow[b]{2}{*}{$\begin{array}{c}\text { Massa } \\
\text { Pasir } \\
\text { Tertinggal } \\
\text { [gram] }\end{array}$} & \multirow[b]{2}{*}{$\begin{array}{c}\text { \% Pasir } \\
\text { Tertinggal }\end{array}$} & \multicolumn{2}{|c|}{$\%$ Kumulatif } \\
\hline No & $\begin{array}{c}\text { Diameter } \\
\text { Lubang } \\
\text { Ayakan } \\
\text { [mm] }\end{array}$ & & & Tinggal & Lolos \\
\hline- & 9,6 & 0,00 & 0,00 & 0,00 & 100,00 \\
\hline 4 & 4,76 & 70,00 & 7,00 & 7,00 & 93,00 \\
\hline 8 & 2,38 & 53,50 & 5,35 & 12,35 & 87,65 \\
\hline 16 & 1,19 & 143,50 & 14,35 & 26,70 & 73,30 \\
\hline 11 & 0,6 & 213,50 & 21,35 & 48,05 & 51,95 \\
\hline 50 & 0,3 & 163,00 & 16,30 & 64,35 & 35,65 \\
\hline 100 & 0,15 & 186,00 & 18,60 & 82,95 & 17,05 \\
\hline pan & - & 170,50 & 17,05 & 100,00 & 0,00 \\
\hline \multicolumn{2}{|c|}{ Jumlah } & $1.000,00$ & 100,00 & 241,40 & \\
\hline
\end{tabular}

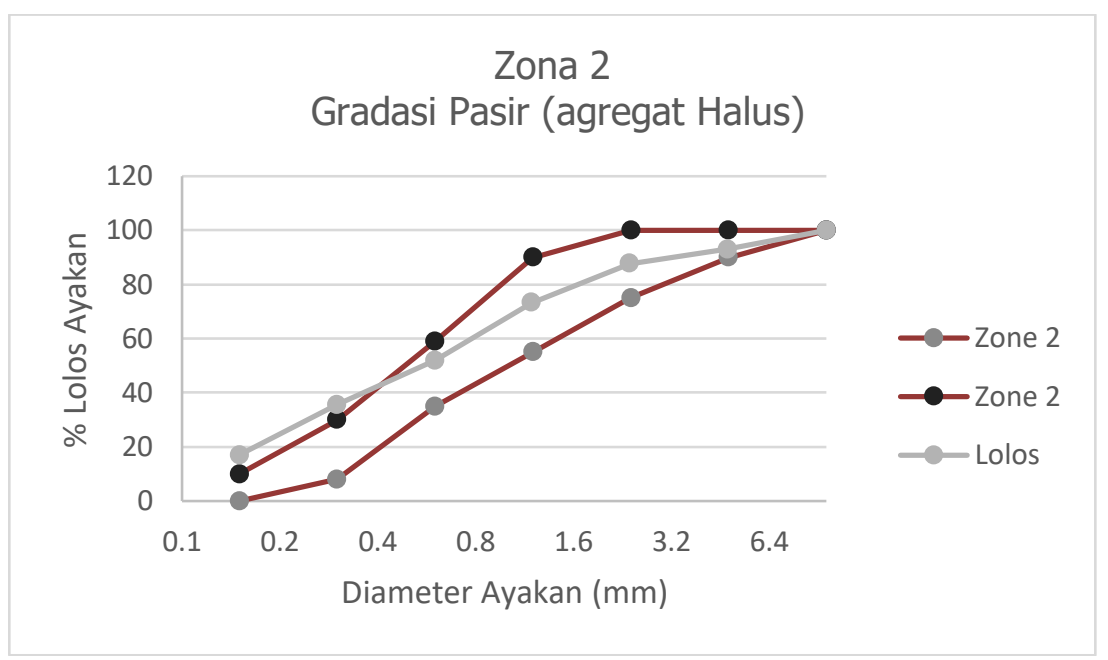

Gambar 2. Hasil analisis gradasi pasir

Hasil analisis pengujian material pasir pada Tabel $\mathbf{1}$ dan Gambar $\mathbf{2}$ menunjukkan bahwa pasir yang digunakan dalam penelitian ini cenderung termasuk ke gradasi Zona 2 dan mempunyai modulus kehalusan sebesar 2,414.

- $\quad$ Semen

Penelitian ini menggunakan Semen Portland Gresik tipe 1.

- Air

Penelitian ini menggunakan air yang berasal dari air PDAM Laboratorium Beton Universitas 17 Agustus 1945 Surabaya.

- Gula

Penelitian ini menggunakan gula pasir denga butiran berwarna putih.

\subsection{Perhitungan Proporsi Campuran Benda Uji Kuat Tekan Mortar}

Perhitungan proporsi benda uji mortar pada penelitian ini mengacu pada peraturan SNI 03-6825-2002. SNI 03-6825-2002 mengatur pembuatan untuk 6 benda uji berbentuk kubus berukuran masing-masing sisinya sebesar $5 \mathrm{~cm}$, komposisi yang digunakan adalah: 
- semen Portland 500 gram;

- pasir 1.375 gram;

- air $242 \mathrm{ml}$.

Proporsi tersebut kemudian disesuaikan dengan ukuran dan volume benda uji mortar yang digunakan.

Perbedaan campuran pada penelitian ini adalah berdasarkan persentase gula yang ditambahkan ke dalam campuran. Terdapat 4 (empat) macam campuran, yaitu: campuran dengan $0 \%$ gula (sebagai benda uji kontrol) serta campuran dengan bahan tambah gula sebesar $0,03 \% ; 0,05 \%$ dan $0,1 \%$ terhadap berat semen. Rekapitulasi hasil perhitungan proporsi campuran benda uji kuat tekan mortar seperti ditunjukkan pada Tabel $\mathbf{2}$ dan Tabel 3.

Tabel 2. Proporsi Campuran Benda Uji dengan Ukuran Diameter $6 \mathrm{~cm}$ dan Tinggi $12 \mathrm{~cm}$

\begin{tabular}{ccccc}
\hline $\begin{array}{c}\text { Jenis } \\
\text { Campuran }\end{array}$ & $\begin{array}{c}\text { Semen } \\
\text { [gram] }\end{array}$ & $\begin{array}{c}\text { Gula } \\
\text { [gram] }\end{array}$ & $\begin{array}{c}\text { Pasir } \\
\text { [gram] }\end{array}$ & $\begin{array}{c}\text { Air } \\
\text { [ml] }\end{array}$ \\
\hline G-0\% & 226,08 & - & 621,72 & 109,423 \\
\hline G-0,03\% & 226,08 & 0,06 & 621,72 & 109,423 \\
\hline G-0,05\% & 226,08 & 0,11 & 621,72 & 109,423 \\
\hline G-0,1\% & 226,08 & 0,23 & 621,72 & 109,423 \\
\hline
\end{tabular}

Tabel 3. Proporsi Campuran untuk Benda Uji Mortar Tiap Mixing (12 Benda Uji)

\begin{tabular}{ccccc}
\hline $\begin{array}{c}\text { Jenis } \\
\text { Campuran }\end{array}$ & $\begin{array}{c}\text { Semen } \\
\text { [gram] }\end{array}$ & $\begin{array}{c}\text { Gula } \\
\text { [gram] }\end{array}$ & $\begin{array}{c}\text { Pasir } \\
\text { [gram] }\end{array}$ & $\begin{array}{c}\text { Air } \\
\text { [ml] }\end{array}$ \\
\hline G-0\% & $2.712,96$ & - & $7.460,64$ & $1.313,07$ \\
\hline G-0,03\% & $2.712,96$ & 0,81 & $7.460,64$ & $1.313,07$ \\
\hline G-0,05\% & $2.712,96$ & 1,36 & $7.460,64$ & $1.313,07$ \\
\hline G-0,1\% & $2.712,96$ & 2,71 & $7.460,64$ & $1.313,07$ \\
\hline
\end{tabular}

Untuk uji kuat tekan mortar, benda uji yang digunakan adalah berupa silinder dengan ukuran $6 \mathrm{~cm}$ pada diameternya dan $12 \mathrm{~cm}$ pada tinggi benda ujinya (Gambar 3). Pengujian kuat tekan dilakukan sebanyak 3 tahap, yaitu: pada umur benda uji 7 hari, 14 hari dan 28 hari; dengan masing-masing benda uji sebanyak 4 buah. Sebelum uji kuat tekan dilakukan, benda uji dirawat terlebih dahulu dengan direndam ke dalam bak curing menggunakan air PDAM Laboratorium Universitas 17 Agustus 1945 Surabaya pada suhu temperatur ruangan (Gambar 4). 


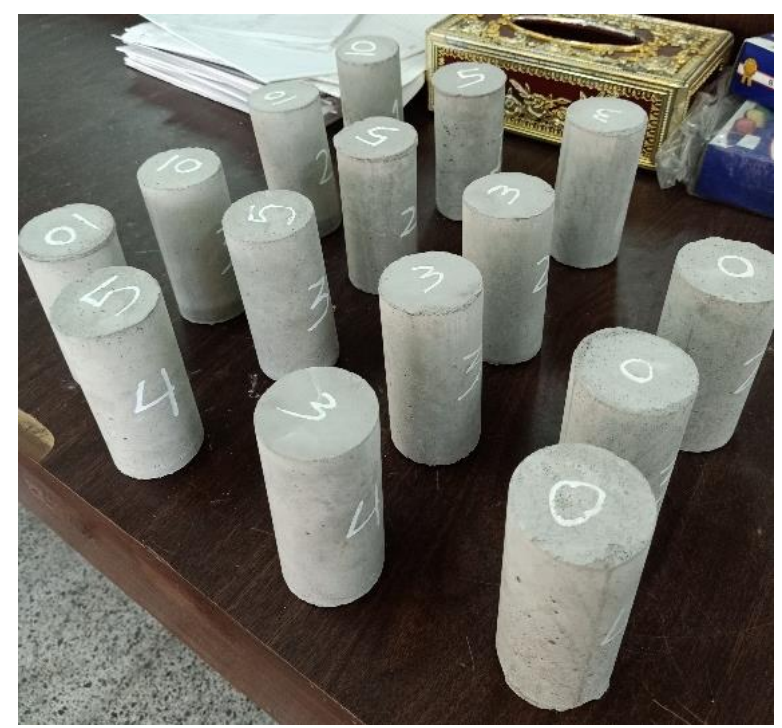

Gambar 3. Benda uji mortar

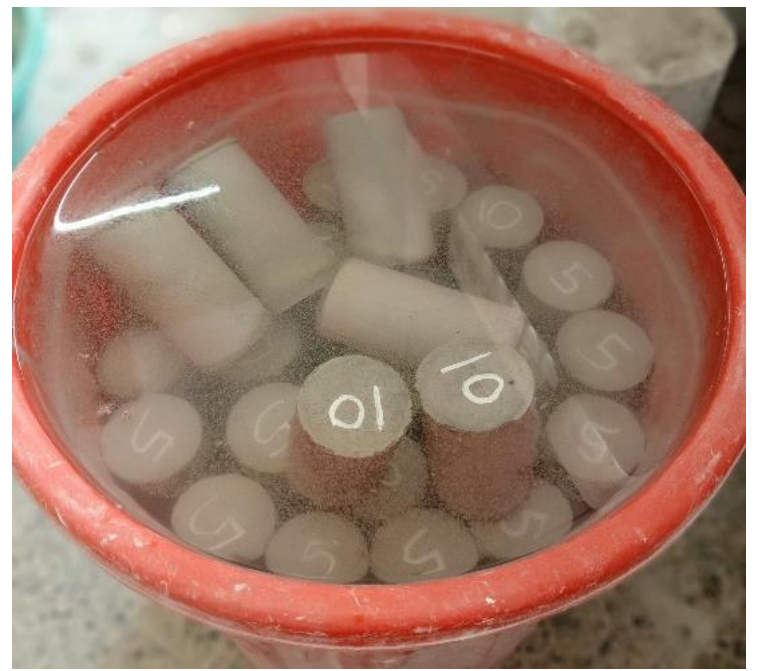

Gambar 4. Perawatan benda uji mortar

\section{HASIL ANALISIS DAN PEMBAHASAN}

\subsection{Hasil Pengujian Waktu Pengikatan Pasta Semen}

Pengujian waktu pengikatan pasta semen bertujuan untuk menentukan waktu ikat awal (initial setting time) dan waktu ikat akhir (final setting time) dari pasta semen. Menurut SNI 6827-2002, waktu ikat awal ditentukan saat jarum vicat masuk ke dalam benda uji pasta sebesar $25 \mathrm{~mm}$ dan waktu ikat akhir pasta adalah saat penetrasi jarum vicat menunjukkan angka $0 \mathrm{~mm}$.

Gambar 5 menjelaskan mengenai hasil pengujian konsistensi normal semen untuk mendapatkan persentase air dalam campuran pasta semen yang sesuai untuk kemudian digunakan dalam pengujian waktu pengikatan dengan menggunakan peralatan jarum vicat. Persentase air yang digunakan adalah persentase dari pasta semen yang memiliki penetrasi ikat sebesar $10 \mathrm{~mm}$ saat 30 detik, yaitu sebesar $23 \%$. 


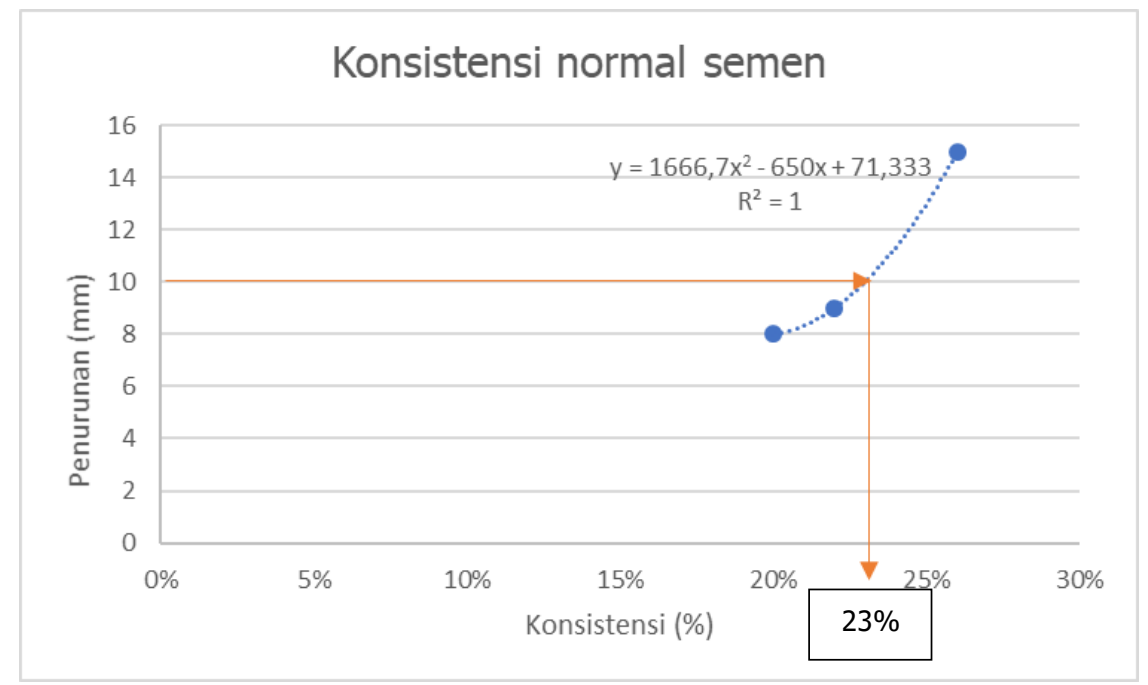

Gambar 5. Hasil pengujian konsistensi normal semen

Pengaruh gula pasir sebagai bahan tambah terhadap waktu pengikatan benda uji pasta semen ditunjukkan pada Gambar 6 dan Tabel 4.

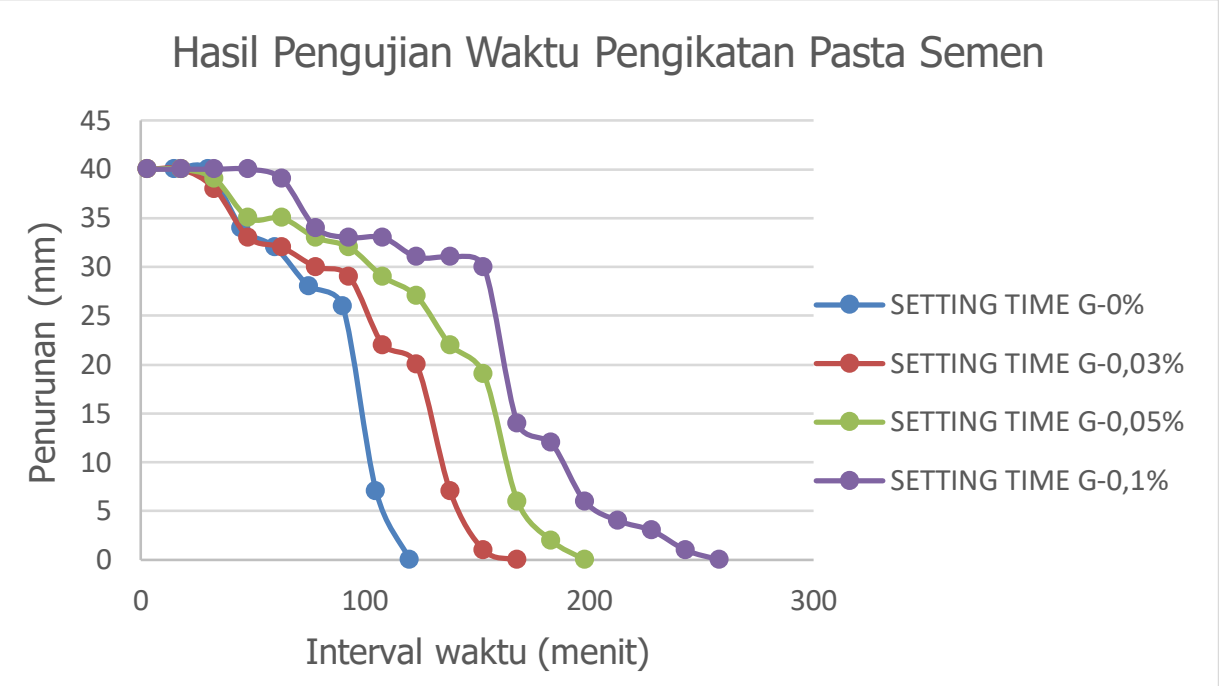

Gambar 6. Hasil pengujian setting time pasta semen terhadap persentase gula

Tabel 4. Hasil Pengujian Waktu Pengikatan Pasta Semen

\begin{tabular}{ccc}
\hline Campuran & $\begin{array}{c}\text { Waktu Ikat Awal } \\
\text { [menit] }\end{array}$ & $\begin{array}{c}\text { Waktu Ikat Akhir } \\
\text { [menit] }\end{array}$ \\
\hline G-0\% & 90,79 & 120,00 \\
\hline G-0,03\% & 101,57 & 168,00 \\
\hline G-0,05\% & 129,00 & 198,00 \\
\hline G-0,1\% & 157,69 & 258,00 \\
\hline
\end{tabular}

Gambar 6 dan Tabel 4 menunjukkan bahwa penambahan gula pasir ke dalam campuran pasta dapat memperlambat waktu pengikatan. Semakin besar persentase gula pasir yang ditambahkan dalam campuran, maka semakin lama pula waktu pengikatan; baik waktu pengikatan awal maupun waktu pengikatan akhir yang terjadi antara semen dan air. Waktu pengikatan awal dan akhir yang paling lama diperoleh campuran G-0,1\% (campuran yang 
mengandung gula pasir sebesar $0,1 \%$ dari berat semen), yaitu sebesar 157,69 menit dan 258 menit. Campuran yang mempunyai waktu pengikatan awal dan waktu pengikatan akhir yang paling pendek adalah campuran G-0\% yang merupakan campuran kontrol, dengan lama waktu pengikatan 90,79 menit untuk waktu pengikatan awal dan 120 menit untuk waktu pengikatan akhir. Hal tersebut terjadi karena butiran semen menyerap molekul gula sehingga membentuk lapisan tipis pada permukaan butiran semen yang kemudian menghalangi semen untuk segera bereaksi dengan air.

\subsection{Hasil Uji KuatTekan Mortar}

Tabel 5, Tabel 6 dan Tabel 7 menampilkan tentang rekapitulasi hasil uji kuat tekan benda uji mortar pada saat umur 7 hari, 14 hari dan 28 hari. Gambar 7 menunjukkan pengaruh bahan tambah gula pasir pada campuran, disajikan dalam bentuk hubungan antara umur benda uji terhadap nilai kuat tekannya untuk benda uji mortar.

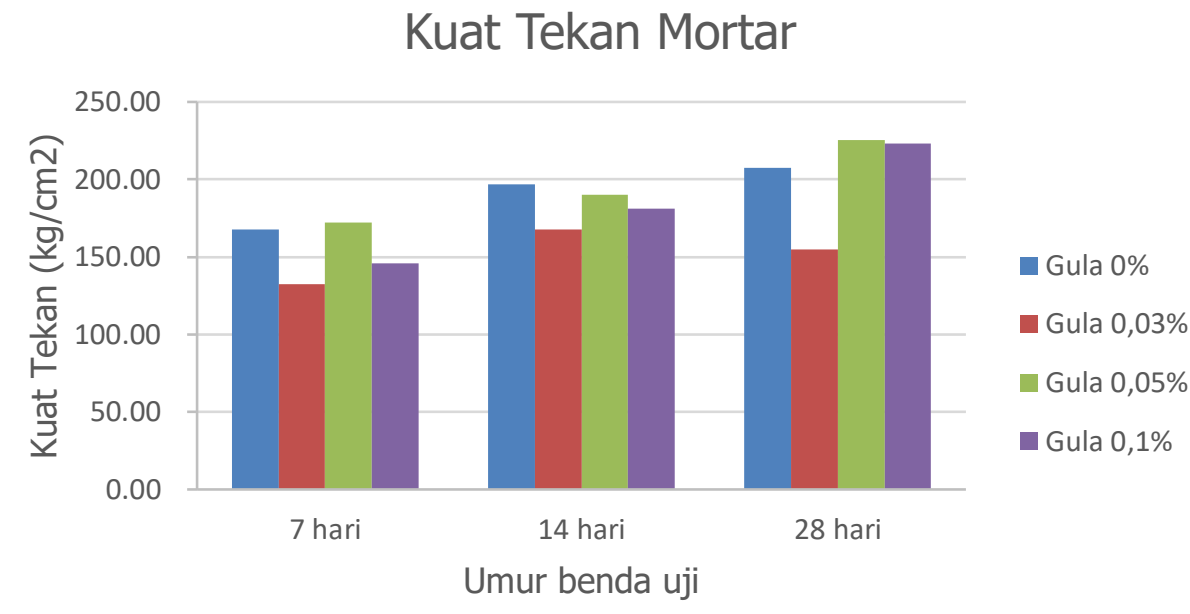

Gambar 7. Hasil uji kuat tekan mortar terhadap persentase gula

Tabel 5. Hasil Uji Kuat Tekan Mortar pada Umur 7 Hari

\begin{tabular}{ccc}
\hline Campuran & $\begin{array}{c}\text { Nilai Kuat Tekan Mortar } \\
\text { pada Umur 7 Hari } \\
{\left[\mathbf{k g} / \mathbf{c m}^{\mathbf{2}} \mathbf{]}\right.}\end{array}$ & Perbandingan \\
\hline $\mathrm{G}-0 \%$ & 167,93 & - \\
\hline $\mathrm{G}-0,03 \%$ & 132,58 & $-21,05 \%$ \\
\hline $\mathrm{G}-0,05 \%$ & 172,35 & $2,63 \%$ \\
\hline $\mathrm{G}-0,1 \%$ & 145,83 & $-13,16 \%$ \\
\hline
\end{tabular}

Tabel 6. Hasil Uji Kuat Tekan Mortar pada Umur 14 Hari

\begin{tabular}{ccc}
\hline Campuran & $\begin{array}{c}\text { Nilai Kuat Tekan Mortar } \\
\text { pada Umur 14 Hari } \\
{\left[\mathbf{k g} / \mathbf{c m}^{2}\right]}\end{array}$ & Perbandingan \\
\hline $\mathrm{G}-0 \%$ & 196,65 & - \\
\hline $\mathrm{G}-0,03 \%$ & 167,93 & $-14,61 \%$ \\
\hline $\mathrm{G}-0,05 \%$ & 190,03 & $-3,37 \%$ \\
\hline $\mathrm{G}-0,1 \%$ & 181,19 & $-7,87 \%$ \\
\hline
\end{tabular}


Tabel 7. Hasil Uji Kuat Tekan Mortar pada Umur 28 Hari

\begin{tabular}{ccc}
\hline Campuran & $\begin{array}{c}\text { Nilai Kuat Tekan Mortar } \\
\text { pada Umur 28 Hari } \\
{\left[\mathbf{k g} / \mathbf{c m}^{\mathbf{2}}\right]}\end{array}$ & Perbandingan \\
\hline $\mathrm{G}-0 \%$ & 207,70 & - \\
\hline $\mathrm{G}-0,03 \%$ & 154,67 & $-25,53 \%$ \\
\hline $\mathrm{G}-0,05 \%$ & 225,38 & $8,51 \%$ \\
\hline $\mathrm{G}-0,1 \%$ & 223,17 & $7,45 \%$ \\
\hline
\end{tabular}

Hasil pengujian kuat tekan menunjukkan bahwa pada umur awal, yaitu saat benda uji berumur 7 hari dan 14 hari, kuat tekan tertinggi diperoleh campuran kontrol (dengan persentase gula $0 \%$ ), yaitu sebesar $167,93 \mathrm{~kg} / \mathrm{cm}^{2}$ dan $196,65 \mathrm{~kg} / \mathrm{cm}^{2}$. Hal tersebut disebabkan karena campuran yang mengandung gula pasir mengalami pengerasan lebih lama. Pada umur 28 hari, persentase gula pasir dalam campuran mortar berpengaruh meningkatkan sedikit kuat tekan pada benda uji mortar.

Hal tersebut berbeda dengan hasil yang ditunjukkan oleh campuran G-0,03\% yang mengalami penurunan kuat tekan yang cukup signifikan, yaitu sebesar $14,61 \%-25,53 \%$ pada umur pengujian 14 hari dan 28 hari. Penurunan kuat tekan tersebut terjadi karena hampir setiap benda uji campuran $\mathrm{G}-0,03 \%$ memiliki permukaan yang miring atau pun tidak rata.

Campuran mortar G-0,05\% mengalami peningkatan kuat tekan sebesar 8,51\% dengan nilai kuat tekan sebesar $225,28 \mathrm{~kg} / \mathrm{cm}^{2}$ pada umur 28 hari. Campuran mortar G-0,1\% juga mengalami peningkatan kuat tekan sebesar 7,45\% dengan nilai kuat tekan sebesar 223,17 $\mathrm{kg} / \mathrm{cm}^{2}$ pada umur 28 hari. Hal tersebut dikarenakan kandungan lignin yang terdapat pada gula berperan dalam meningkatkan lekatan antar penyusun campuran mortar (Bunganaen, 2016).

\section{KESIMPULAN}

Penambahan gula pasir pada campuran pasta semen berpengaruh pada lamanya waktu pengikatan. Semakin banyak persentase gula yang ditambahkan ke dalam campuran, semakin lama pula waktu pengikatan awal dan waktu pengikatan akhir dari campuran pasta semen. Hal tersebut dikarenakan molekul gula terserap dalam butiran semen sehingga membungkus permukaan semen dan menghalangi terjadinya pengikatan antara semen dan air. Campuran G-0,1\% mempunyai waktu pengikatan awal dan waktu pengikatan akhir terpanjang, yaitu 157 menit dan 258 menit.

Penambahan gula pasir terhadap kuat tekan mortar tidak berpengaruh terlalu signifikan. Kuat tekan pada campuran G-0,05\% dan G-0,1\% mengalami kenaikan sebesar $8,51 \%$ dan $7,45 \%$ terhadap kuat tekan benda uji kontrol. Hal tersebut disebabkan oleh lignin yang terkandung dalam gula dapat meningkatkan lekatan antar komponen penyusun mortar. Kuat tekan tertinggi diperoleh campuran G-0,05\% sebesar 225,38 kg/cm². 


\section{UCAPAN TERIMA KASIH}

Penulis mengucapkan rasa syukur kepada Allah Subhanallahu wa Ta'ala dan terima kasih kepada institusi Universitas 17 Agustus 1945 Surabaya yang telah membantu kami dalam menyelesaikan penelitian ini.

\section{DAFTAR RUJUKAN}

Badan Standardisasi Nasional. 2002. SNI 03-6825-2002 tentang Metode Pengujian Kuat Tekan Mortar Semen Portland untuk Pekerjaan Sipil. Jakarta: Badan Standardisasi Nasional.

Badan Standardisasi Nasional. 2002. SNI 03-6826-2002 tentang Metode Pengujian Konsistensi Normal Semen Portland dengan Alat Vicat untuk Pekerjaan Sipil. Jakarta: Badan Standardisasi Nasional.

Badan Standardisasi Nasional. 2002. SNI 03-6827-2002 tentang Metode Pengujian Waktu Ikat Awal Semen Portland dengan Menggunakan Alat Vicat untuk Pekerjaan Sipil. Jakarta: Badan Standardisasi Nasional.

Bunganaen, W., Elia H., Yustanius Bei-Ngala. (2016). Pengaruh Penambahan Gula Pasir terhadap Kuat Tekan dan Sifat Kedap Air Mortar. Jurnal Teknik Sipil, 5(1), 105-116.

Khan, B., Muhammad Ullah. (2004). Effect of a Retarding Admixture on the Setting Time of Cement Pastes in Hot Weather. JKAU: Eng. SCi, 15(1), 63-79.

Neville, A.M., J.J. Brooks. (2010). Concrete Technology. London: Pearson.

Subakti, A. , Irmawan, M., Piscesa, B., (2010). Teknologi Beton dalam Praktek. Surabaya: ITS Press. 